\title{
RAILWAYS IN LITHUANIA: FROM TSARIST RUSSIA TO RAIL BALTICA
}

\author{
Lijana MASKELIŪNAITE $\dot{E}^{*}$ \\ Dept of Mobile Machinery and Railway Transport, Vilnius Gediminas Technical University, Lithuania
}

Submitted 13 August 2021; resubmitted 4 October 2021; accepted 6 November 2021

\begin{abstract}
Lithuania is a transit country. It is a small but significant territory between East and West. This fact is substantiated by the history of the country railways, which started when Tsarist Russia launched the construction of the railway between Saint-Petersburg and Warsaw. There is not much research into the history of railways in Russia, also in Lithuania. Besides, not all available information is reliable due to the nihilistic attitudes towards Tsarism of that time. Only some of the railways in the former Soviet Union were written and talked about. The history of the Lithuania railway is not an exception. Different written sources provide a variety of dates for the first railway to be built in Lithuania. They mirror varied events in the history of Lithuanian railways, thus all of them must be taken into consideration. The article presents the evolution of Lithuanian railway transport from Tsarist Russia to Rail Baltica, which is the European railway project currently implemented in Lithuania. The article discusses the world's first railways including the ones in Tsarist Russia when the history of Lithuanian railways started. The article also considers the building of the first railway in Lithuania, construction of railway stations, setting the transportation tariffs, selection of railway employees. The author of the article employs historical and online resources as well as a long-standing personal experience in railway transport. The research into Tsar Family's diaries and historical novels makes it possible to disclose the facts that are not widely known. The author considers the future of Lithuania with reference to the construction of the European railway Rail Baltica. The article would be useful for the readers who are interested in the historical development and future of Lithuanian railways.
\end{abstract}

Keywords: the world's first railways, Saint-Petersburg-Warsaw railway, Lithuania, railway station Verzhbolovo, Rail Baltica, transport history, Lithuanian railways.

\section{Introduction}

The origin of the railway dates back to ancient Greece and Egypt, where guided ways was already known. The Greeks had the so-called sacred roads used to push their god sculptures, which were put on wheeled pallets. The front and rear wheel axles had a uniform track. To prevent the sliding of gods from the track, the Greeks carved grooves for the wheels in the rock pavement. The gods moving through these grooves could pass each other when the ceremony ritual required that. Similar devices were known to the ancient Egyptians too. They used them in construction when transporting huge blocks of rock. The beam bearing road was a direct prototype of the upper road structure of modern railways. It was originally used for towing readymade flat surfaces, which were put on wheels in the mid 17th century mines of England and Germany. The wooden beam rails had an equal distance between the inner edges therefore trolley wheels were made with flanges on the inside so as not to slip away from the beams. In 1767, the wooden flat surfaces were replaced by wooden beams were topped with iron plates. The durability of the latter compared to the wooden ones, albeit reinforced with metal strips, also the ease of rolling the trolleys, speeded for a quick change of the wooden rails in the mines. The rails made of iron started to be produced. The most suitable profile was also searched for (Žeimantas 2003).

The history of European railways was complicated. The first public rail transport started to function in 1820. It was a set of horse-drawn carriages loaded on rails (Vanagas 2017). The first railway line appeared in England in 1825. Soon, the invention spread to France, Prussia, the US, even India and South America (Venclova 2019). With the introduction of the first rails in the first half of the19th century, it became possible to transport large numbers of people and goods by land over long distances, quickly and economically. The railways became the engine of European industrial growth, with the rail network expanding across Europe. However, during World War II, much of the trans-European railway infrastructure was damaged

*E-mail: lijana.maskeliunaite@vilniustech.lt 
and not reconstructed. After the war, the Iron Curtain divided the European continent and the division lasted for several decades. There was a decrease in the role of the railways in Europe. More attention was paid to the development of road transport infrastructure (Rail-Baltica.lt 2021b).

Lithuania was occupied by Tsarist Russia and innovations reached the country with considerable delays. Therefore, for a long time, life in Lithuania was much the same as in the 18th or earlier centuries (Venclova 2019). The history of Lithuanian railway begins with the launch of Saint-Petersburg-Warsaw railway construction. With the advent of railways in the US and Europe, Russia was still considering whether the country needed them. To this day, legends are circulating about the start of the construction of the Russian railway. According to one of the stories, Tsar of Russia Nicholas I drew a line of the future railway on a map and penciled around his finger attached to the ruler, resulting in a line with a curve popularly known as the "emperor's finger". It is symbolic, but after many years, his grandson had to renounce the throne on the train. Tsar Nicholas I, who decided to build railways in Russia, could have hardly imagined such development of events (Horvatova 2011). In her diary, Duchess E. A. Naryshkina wrote: "The ruler has signed a renunciation of the throne for himself and for his son. The Tsar's train was stopped in Pskov. Despair! ..." (in Russian: Gosudar' podpisal otrechenie za sebja i za syna. Carskij poezd byl astanovlen $v$ Pskove. Otchajanie!...) (Hrustalev 2008).

Tragic events are also recorded in the pages of Lithuanian history. On 14 June 1941, the People's Commissariat of Internal Affairs (in Russian: NKVD - Narodnyj komissariat vnutrennih del) began mass arrests and deportations of Lithuanians to Siberia. People were put into wooden freight wagons meant to transport cattle and deported to Siberia. There, the deportees faced hunger, cold and forced labour. They had to dig the frozen Siberian earth for a piece of bread. "We disembarked from the lorry, then the guards made us go to the railway platform where a long red echelon of the cattle wagons was standing. There were hundreds of people - men, women, children, and elderly people. They were surrounded by the guard armed with rifles and bayonets. People were pushed into wagons. When a wagon was full, its doors were closed and screwed with bolts" (Venclova 2019).

To this day, rail transport is popular all over the world: railways and rolling stock are regularly improved, the quality of passenger service enhanced, travel safety increased. All this facilitates rail transport in the competition with other modes of transport. The fatality risk for an average train passenger is now about 0.05 fatalities per billion passenger kilometres, making it comparatively the safest mode of land transport in the EU (ERA 2020).

Lithuanian scientists are researching railway transport infrastructure, rolling stock and transportation processes. The research by Gailiene (2012) presents the method in Lithuania for calculating superelevation in the railway curves and analyses calculation defects. Navikas et al. (2018) presents investigation and evaluation of railway ballast properties variation during technological processes. In the research by Navikas et al. (2016) density and water permeability of 49 produced random samples of aggregate sub-ballast mixture, which were taken from the stockpile in the plant and from the uncompacted railway layer are investigated. The research by Bogdevičius et al. (2015) examines a mathematical model for the system "railwayvehicle wheel - track" that allows examining the interaction between a wheel flat and a rail in the vertical plane. Estimated of a passenger car ride smoothness under various exploitation conditions (Vaičiūnas et al. 2021). Train travel quality criteria related to train elements and railway track technical condition (Maskeliūnaitè, Sivilevičius 2014), train travel process organization and technology (Sivilevičius et al. 2012), travel price (Sivilevičius, Maskeliūnaitè 2019) and train travel safety (Maskeliūnaité, Sivilevičius 2020) are systematically assessed. A multi-criteria and reverse hierarchy model is applied, substantiating the choice to travel by rail as an alternative to air and road transport (Sivilevičius, Maskeliūnaitė 2018).

Freight wagon body reliability studies are being performed (Li et al. 2020). Earth climate warming due to anthropological pollution is forcing the search for sustainable solutions in the transport sector. The assessment of greenhouse gas emissions has become a major goal for transportation companies (Mintzia et al. 2018). According to data provided by the EC, the amount of greenhouse gasses emitted by the EU railways in 2017 was lower than $0.5 \%$. Therefore, trains are one of the most sustainable means of transporting passengers and freight. An infrastructure network for electric traction trains is being developed across Europe. However, only about $7 \%$ of passengers and $11 \%$ of freight are transported by rail. History may turn again - this time in a direction favourable to railways (Rail-Baltica.lt 2021b). However, let us start from the beginning.

The aim of the article is to view the development of the world's first railways, including the ones in Russia, which influenced the development of Lithuanian railways. In addition, to study the dynamics of railway construction in Lithuania and future works related to the European railway Rail Baltica, which is currently under construction.

\section{Construction of the world's first railways}

From 1830 onwards, proponents of the new mode of transport in Russia used to raise the question of the construction of the railway in the country. Russian Tsar Nicholas I was against the construction of the railway at the time. And as is usually the case with an authoritarian regime, the elite of the Russian society was also against it. By this, these people tried to show full trust in the first-person's opinion and judgement. The question stands up why the Tsar and his supporters were against the construction of railways in Russia. A decision from the Ministers Cabi- 
net said that the railway "would bring a harmful foreign spirit to Russia" (in Russian: zaneset $v$ Rossiju vrednyj duh inostrannyj). The conservatism of Tsar Nicholas I towards construction of railways was not an exception. Finance Minister Count E. F. Kankrin wrote that the railways would destroy the "indispensable hierarchy of the society" (in Russian: stol' neobhodimuju obshhestvennuju ierarhiju), as the new mode of transport would lead to "equality of strata because the official and a country bumpkin, a gentleman and a commoner will sit in the train next to each other, in the same row" (in Russian: privedet $k$ ravenstvu soslovij, tak kak i sanovnik i prostak, barin i muzhik poedut, sidja rjadom $v$ vagone, $v$ odnom posade).

The similar situation was observed in other countries, where the economic situation depended on the people in power. The Austrian Emperor Franz Joseph was also categorically opposed to the construction of the railway. When he was offered the Northern railway project, he said: "No no, I'm not going to do this because a railway can become the route for the revolution to come to this country!". In addition to the political counterarguments, the engineers raised technical arguments and some of them were very serious. For example, how to heat passenger cars, how to avoid a fire that could be generated by steam locomotive sparks, how to clear snow from the road. However, while Russia was deliberating, the world countries were acting. Great Britain became the pioneer in railway construction (Table 1). In the period of 1828-1835, the railways in Austria, France, the US, the Czech lands, Scotland, Ireland, Belgium, and Germany started to function (Husainov 2021).

The decision to build railways in Russia was made in 1835, when Franz Anton von Gerstner, an engineer from Austria and a professor at the Vienna Polytechnic Institute, in a personal meeting convinced Nicholas I that the Tsar "must prove to Europe that he is not feeble-minded and sleepy as Europeans imagine him to be" (in Russian: dolzhen zhe car' dokazat' Evrope, chto on ne takoj otstalyj $i$ dremuchij, kakim kazhetsja evropejcam). It was then decided to convene a special committee for the construction of railways in Russia (in Russian: special'nyj osobyj komitet po obustrojstvu zheleznyh dorog $v$ Rossii). The first meeting of the committee was held on 28 February 1835. Tsar Nicholas I participated in the meeting and outlined the benefits of building a railway. All the members who the day before unanimously voted against the construction of railways in Russia changed their views in an instant and unanimously voted for the construction of railways. The first Russian railway was officially opened in 1837 and this date is considered the beginning of rail transport in Russia. The first railway connected Saint-Petersburg and Tsarskoe Selo (Husainov 2021).

In the period of 1843-1851 the railway Saint-Petersburg-Moscow was built, which became famous for its luxury and as an example of mismanagement and inefficiency. After completing the construction of the first railway, the government started the second, Saint-Petersburg-Warsaw with a branch to Prussia (Žeimantas 2003). The railway track went through the major cities: Pskov, Dvinsk, Vilnius (at that time was named in Polish: Wilno), Kaunas (at that time was named in Polish: Kowno), Grodno, Białystok (Figure 1a). The technical parameters of the railway SaintPetersburg-Warsaw are presented in Table 2. The gauge of the railway Saint-Petersburg-Warsaw was $1524 \mathrm{~mm}$. The first railways of this gauge were built in Great Britain and the US. It is possible that the $1524 \mathrm{~mm}$ gauge was chosen by Russia because the railway construction consultants were from America.

In addition, it cannot be excluded that the choice of track gauge was influenced by the military aspect - a track other than the European track would make it more difficult for an enemy to invade Russia, deploy and supply

Table 1. World's first railways - entry into service (Husainov 2021)

\begin{tabular}{|l|c|l|c|}
\hline Country/region & Year when the first railway entered into service & \multicolumn{1}{|c|}{ Railway line } & Length [km] \\
\hline Great Britain & 1825 & Stockton-Darlington & 41 \\
\hline Austria & 1828 & Budejovice-Kirschbaum & 64 \\
\hline France & 1828 & Saint-Etienne-Andrecix & 18 \\
\hline US & 1830 & Baltimore-Elicott-Milz & 24 \\
\hline Czeck lands & 1830 & Prague-Lana & 57 \\
\hline Scotland & 1832 & Edinburgh-Dalkeith & 19 \\
\hline Ireland & 1834 & Dublin-Kingstown & 10 \\
\hline Belgium & 1835 & Brussels-Mechelen & 20 \\
\hline Germany & 1835 & Nuremberg-Fürth & 6 \\
\hline Russia & 1837 & Saint-Petersburg-Tsarskoe Selo & 27 \\
\hline Italy & 1839 & Naples-Portezi & 8 \\
\hline Denmark & 1839 & Amsterdam-Haarlem & 16 \\
\hline Cuba & 1840 & Havana-Guinai & 50 \\
\hline Poland & 1846 & Warsaw-Częstochowa & 24 \\
\hline Switzerland & 1847 & Zurich-Baden & 251 \\
\hline
\end{tabular}


Table 2. The technical parameters of the railway SaintPetersburg-Warsaw

\begin{tabular}{|l|l|}
\hline \multicolumn{1}{|c|}{ Parameter } & \multicolumn{1}{c|}{ Dimension } \\
\hline Track gauge & $1524 \mathrm{~mm}$ \\
\hline Marginal slope & $0.006 \%$ o \\
\hline Minimum radius of curve & $1065 \mathrm{~m}$ \\
\hline Length of iron rail & $4.2 \ldots 6.0 \mathrm{~m}$ \\
\hline Rail (meter) weight & $32.49 \ldots 35.6 \mathrm{~kg} / \mathrm{m}$ \\
\hline Height of ballast prism (under sleepers) & $30 \ldots 50 \mathrm{~cm}$ \\
\hline Wooden sleepers & 1200 units $/ \mathrm{km}$ \\
\hline Length of sleepers & $2.7 \mathrm{~m}$ \\
\hline Earthworks (volume) & up to $76000 \mathrm{~m}^{3} / \mathrm{km}$ \\
\hline
\end{tabular}

troops (Prizova 2014). This track gauge was accepted by the builders of the railway Nikolaevsky and became the gauge of all Russian railways. The uniform track gauge in other countries was adopted much later.

It was not easy to build the first railways: there was a lack of special equipment and manpower. Those who wanted to earn money were not free, they were serfs. It was not easy to get to work from far away places. Trains or buses did not exist then. Workers could only come to the workplace on foot. Large gatherings of people provoked the diseases (Žeimantas 2003). In some sections of the road, due to the lack of quality soil, clay was used to make embankments. While dry, it is strong enough, but when wet clay gets soft, so low embankments with slopes of $1: 3$ were made (Figure $2 a$ ).

The rails for the railway Saint-Petersburg - Warsaw were supplied by the P. Demidov and S. Yakovlev Ural mining plants. These rails were two to three times more expensive than the English ones, but they were famous for their better quality. The rails were also purchased from English companies, but only till the beginning of the Crimean War. Initially, the railway had $4.2 \ldots 6.0 \mathrm{~m}$ long rails. Later, in 1870 , the iron rails were replaced by 35.60 and $32.49 \mathrm{~kg} / \mathrm{m}$ rails with steel heads and steel rails. The joint was made on the sleeper and tightened with 4 screws. About 1200 units of wooden sleepers were laid per kilometre of the railway. Sand, a mixture of sand and a)

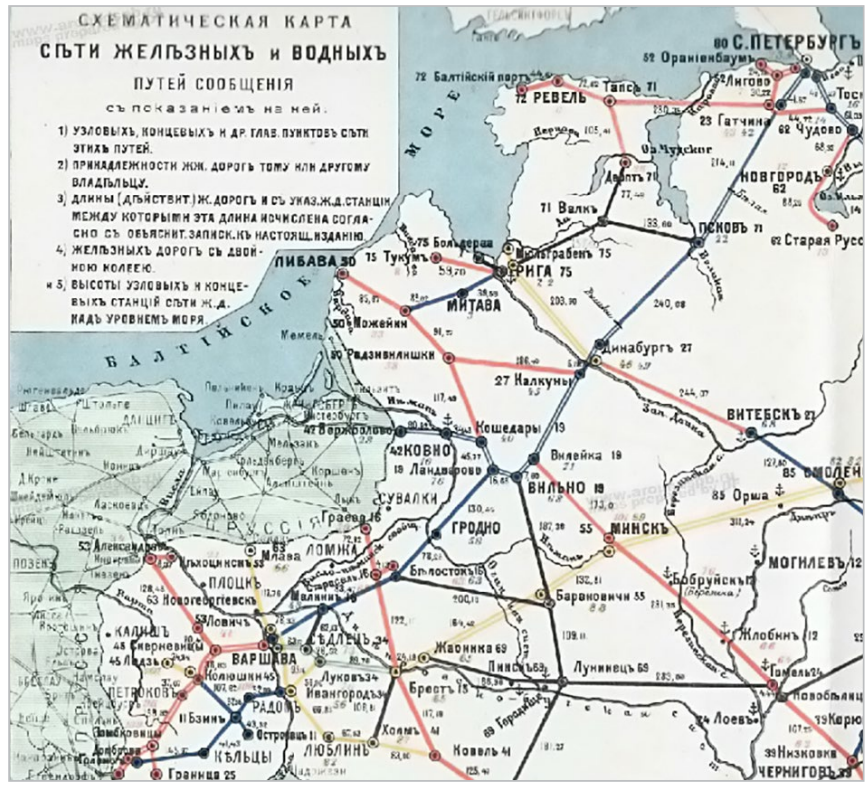

b)

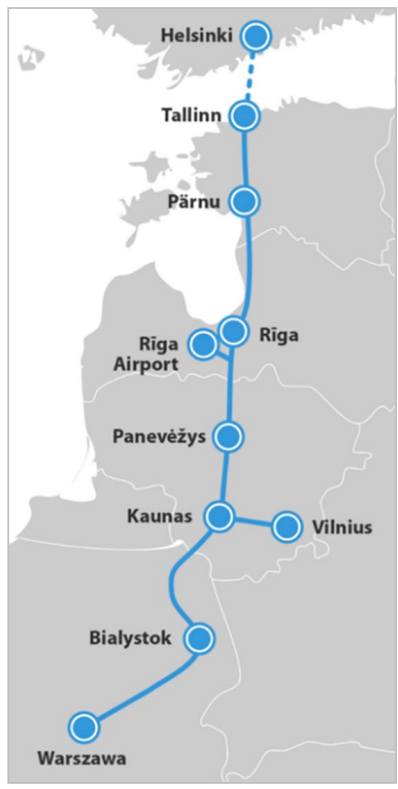

Figure 1. Map of the railway line: a - Saint-Petersburg-Warsaw railway line (in Russian) (ID 2021); b - European railway Rail Baltica line (LR SM 2021a)

a)

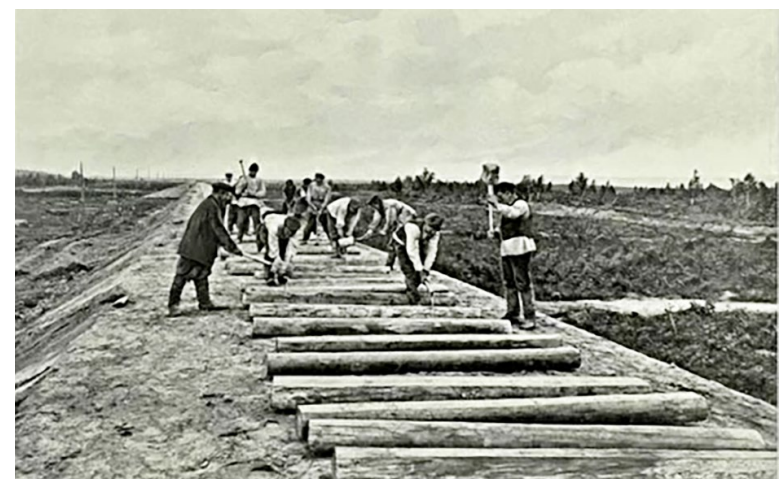

b)

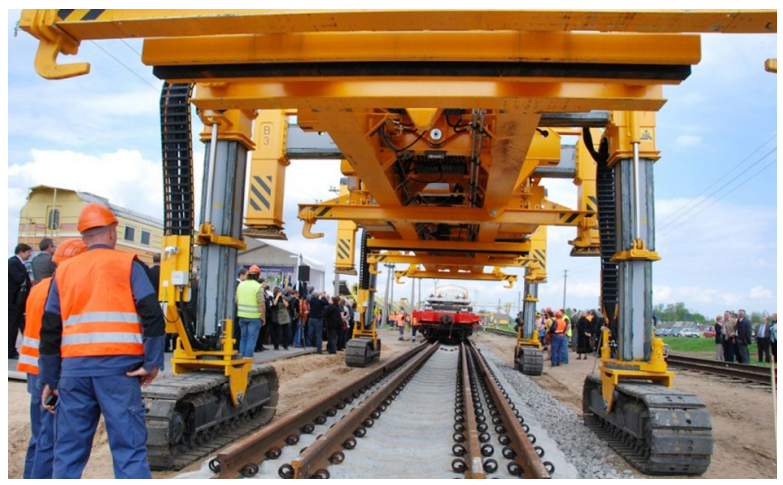

Figure 2. Railway construction: a - construction of the first railways (Husainov 2021); b - Rail Baltica construction works (LR SM 2021e) 
gravel, and in some sections stone chippings were used for the ballast. The sleepers for the Saint-Petersburg-Warsaw railway were impregnated with a mixture of creosote (a greasy, strong-smelling liquid obtained from wood or coal tar and used in technology, medicine) and zinc chloride. The railway company had a sleeper impregnation plant. An effective method was used to combat the unevenness of the earth embankments. Soil was changed in those places. To protect the road from snow, plants were put on the sides. It was a novelty in those days (ID 2021).

Saint-Petersburg-Warsaw railway line was serviced by 101 steam locomotives. The speed of freight locomotives was up to $40 \ldots 45 \mathrm{~km} / \mathrm{h}$, the speed of passenger trains was up to $80 \mathrm{~km} / \mathrm{h}$ (ID 2021).

\section{The first railways in Lithuania}

The first railway construction projects in Lithuania are related to the Liepaja-Jurbarkas and Saint-Petersburg-Warsaw lines. The idea of Saint-Petersburg-Warsaw railway line was first raised in 1835 by V. Gur'ev who was a Russian. He offered to connect Saint-Petersburg and Warsaw via Riga and Grodno. In 1838, M. Murav'jov who also was Russian, expressed the idea to connect Saint-Petersburg and Warsaw by building a railway via Daugavpils, Vilnius and Grodno. Almost at the same time, the project to build railways was presented by F. Garsten, a Czech who served in Tsar's office and was one of the owners of the first Russian railway connecting Saint-Petersburg-Tsarskoye Selo. His project was the same as M. Murav'jov's proposal, but also pointed to the need to build a branch to Prussia. In 1851, the Russian government passed a resolution on the construction of the railway Saint-Petersburg-Warsaw. The route indicated by F. Garsten was chosen. The length of the railway was estimated at about 1250 kilometres. Officially the construction of the railway line started on 15 February 1851 (Žeimantas 2003).

The construction of the Daugavpils-Vilnius-KaunasKybartai (Virbalis) railway section was undertaken by the merchant G. Adelson, who had the central construction office in Vilnius. The works on the road Daugavpils-Vilnius-Lentvaris-Kaunas-Kybartai started on 1 May 1859. The railway station under construction in Kybartai was named Virbalis (in Russian: Verzhbolovo), therefore this section for a long time was officially called Kaunas-Virbalis. It was not difficult to build a railway across the Sūduva plain, as no major earthworks were required. The biggest problem was posed by the river Nemunas. The road from the border to the banks of the Nemunas was completed in 1861. On 28 April 1860, the General Affairs Department of the Ministry of the Interior informed the Governor General of Vilnius that Grand Duchess Jelena Pavlovna would travel abroad: from Saint-Petersburg to Daugavpils by rail, from Daugavpils to Kaunas and Virbalis on the road. On 12 September of the same year, the son of the Tsar and the heir to the throne, went to Warsaw. He travelled to Daugavpils by train, then by horse via Ukmerge and Kaunas.
These two travel routes of high-ranking state figures show that there was no integrated railway from SaintPetersburg to Vilnius at that time. The train that came to Vilnius from Daugavpils was first mentioned in the press on 4 September 1860 . Yet, it was the train on the left side of the Daugava specially coupled for the Tsar. The event got into the press due to the visit of the emperor. There was no public transport at that time because it was held up by unfinished works, especially the bridge being built across the Daugava. The construction of the bridge was completed only in 1862 . On 15 March 1862, train route from Saint-Petersburg to Vilnius and from Vilnius to Virbalis was opened. Regular trains to Warsaw were launched on 15 December 1862. The list of the first dates can be continued. Nonetheless, the most prominent are the two dates: 15 May 1858, when the works in the construction of the railway in Lithuania started (beginning of the railway era in Lithuania) and 11 April 1861, when public rail traffic Kaunas-Virbalis (Kybartai) was opened. For this event, 10 freight locomotives were ordered abroad in advance, which were transported to Kaunas in 1860 (Žeimantas 2003).

The company report notes that a lot of time was wasted to order passenger railway wagons. It took a long time to develop technical specifications suitable for the harsh climate of Russia, because the railway wagons of Western Europe were not heated at that time. The company expected to have enough passenger and freight railway wagons by opening traffic in the Kaunas-Virbalis section. Indeed, on 31 December 1861, there were already 11 freight train locomotives, 43 passenger and baggage wagons, 6 freightpassenger wagons, 148 freight and 300 ballast railway wagons in Kaunas-Virbalis section (Žeimantas 2003).

4 September 1860, which marks the date of the first train when the Tsar came to Vilnius, cannot be seriously considered. This train could not be the first to Vilnius because of the simple matter: rulers are never testers. The Tsar could go on the railway that had been pretested. And pretesting was done by those who carried out the works of the railway, thus the date of the first train entry to Vilnius was not recorded (Žeimantas 2003). By the way, if we are to believe the reference (Kunčius 2018), the commander of the world proletariat V. I. Lenin travelled in the first-class wagon of the Saint-Petersburg-Warsaw train. Members of the organization "Combat Union for the Workers' Class Liberation" were worried that Lenin had recently been looking very tired, and by a majority of votes they decided to send him to Warsaw for a few days. On the train, Lenin met S. G. Petuchov, a friend from the gymnasium class. The accidental meeting of the classmates meant that such an event had to be 'marked'. The warm meeting of the classmates ended in an unexpected way. In the morning of 19 September 1895, V. I. Lenin was disembarked from the train in Vilnius.

After the construction of the Saint-Petersburg-Warsaw railway in the current territory of Lithuania, the following train stations were built: of the highest class - Lentvaris 
and Virbalis (at that time was named Verzhbolovo), firstclass - Vilnius and Kaunas, second class - Švenčionèliai, third class - Dūkštas, Kazlų Rūda, Varèna and Žasliai, fourth class - Bezdonys, Ignalina, Mauručiai, Pabradè, Pilviškiai, Rūdiškès, Turmantas, Valkininkai, Marcinkoniai, Vievis and Vilkaviškis. In the times of the Russian Empire, Kybartai station was the largest after Saint-Petersburg railway station (Žeimantas 2003). On the one side of the station, there was Russian gauge railway $(1524 \mathrm{~mm})$ and on the other side of the station there was European gauge railway $(1435 \mathrm{~mm})$ (Ivaškevičius 2013b). At the beginning of the 20th century, there was a widespread saying in the Russian Empire: "Everything that is new is only to Virbalis - what is new here is not new over there" (in Russian: Vsjo novo lish' do Verzhbolova - chto novo zdes', to tam ne novo). Today, one hundred years later, it is almost impossible to understand what it means. Similarly, confusing is a rebellious statement of twenty-year-old V. Mayakovsky, which was published in the Russian press in 1914: "It is time to understand that "to be Europe" for us is not a slave copying of the West or walking on suspender belts thrown at us through Verzhbolovo. It means accumulating our strength as is done there". In 1913, Verzhbolovo station was also mentioned in the poem "To Russia" by I. Jerenburg, a young Russian symbolist living in Paris at the time: "If again I see porters, and the word on the wall "Verzhbolovo" <...> I will understand how weak I am against you, and how much have I wasted in these years" (in Russian: Esli ja kogda-nibud' uvizhu snova, i nosil'shhikov i nadpis' "Verzhbolovo" <...> Ja pojmu kak pred toboj ja nishh i mal, kak ja mnogo v jeti gody rasterjal) (Ivaškevičius 2013a).

According to the writer V. Nabokov, Virbalis was the place "where the angular Russian railway was changed to a narrow European railway, where birch firewood was changed to coal". The station building was designed by the French and built by the Germans. In Tsarist Russia there was a prohibition on photographing the border area, railway lines, bridges, and territory around. The distance from these objects had to be no less than 5 measurements that were used in Russia in the late-18th-early-19th centuries. The distance equalled to 500 fathoms in length $(1.067 \mathrm{~km})$. However, with the permission of the Minister of the Interior exceptions were made. Therefore, the postcards picturing railway crossings and railway stations (Figure 3a) are available today and they are a perfect witness of what the places looked like at that time. The station building was an impressive building - huge halls, hotels, and restaurants of three classes, outdoor tennis courts, bowling alley, Tsar family apartments. The garage was also built to house a personal luxury Tsar train. It was made ready for the Emperor to have a ride in Europe.

The Virbalis customs point was the most important one on the western border of Russia. In 1914, it was the locality where about a tenth of Russian Empire goods were exported to the West. The goods included timber, grain, flax, linseed, birds, horses, pork, fruit, which were mostly transported from Lithuania (or through Lithuania) to the
West. Fish (herring), grain, fertilizers, coal, metalworking and agricultural machinery, seeds were imported to Lithuania from East Prussia. Illegal communist content books were secretly brought to Lithuania via Virbalis. Therefore, train passengers were usually thoroughly searched. In 1895, customs officers also searched Lenin, who arrived in Virbalis from Eitkūnai. However, no prohibited literature was found in his luggage. The remains of famous people were also transported to Russia via Virbalis. In July 1904, the remains of the writer A. Chekhov were transported in a galvanized coffin via Virbalis (Veidas.lt 2010). The writer's body was "brought to Moscow from Germany in a railway wagon with refrigeration equipment and the wording "The transport of fresh oysters'”. Because of this Alexei Peškov (Maxim Gorky) was greatly annoyed. He wrote: "Anton Pavlovich, who was disgusted at everything banal and vulgar, was brought in a railway wagon "to transport fresh oysters". It is breathtaking and I want to howl, outcry and fight. For him, no difference. You can carry his body in a basket of dirty laundry. But for us, Russian people, I can't forgive this "oyster wagon"' (Zygar 2020).

During World War I, the Russian Verzhbolovo became the German Wirballen, and in 1918, this huge station went to Lithuania that was an independent country. It was hard for a small state to operate such a large building, so the Kybartai Court settled in the former apartments of the Tsar. The large passenger hall was the place where people of Kybartai used to have the New Year celebrations. Sometimes the hall was used as the basketball court. Virbalis station successfully survived the beginning of World War II. At the end of the war the building was damaged, yet it could be restored. Nevertheless, the survival of the building was determined by a misunderstanding. The Soviet authorities were constantly confusing Kybartai station and Eitkūnai station, which was nearby. In 1944, Russian soldiers were ordered to demolish the Eitkūnai station building, which had been significantly damaged. However, they made a mistake and began to demolish the walls of the Virbalis station. In this way, the building of the customs and railway station, which survived 83 years and was used by various governments and states was demolished (Veidas.lt 2010). The present Kybartai railway station is shown in Figure $3 b$.

Kaunas station was opened on 11 April 1861, when railway traffic on the Kaunas-Virbalis branch started. A large two-storey brick building with halls for first-, second- and third-class passengers, offices for station administration and doctor's room as well as 15 apartments for railway employees were built. A locomotive depot was established. Kaunas tunnel (Figure 4a) received special attention from the government (Žeimantas 2003). It is one of the oldest operating tunnels in Europe and the only one in the Baltic countries that has survived two wars and one blast. In 1944, German soldiers while retreating used 7 explosive-loaded wagons and blew up the tunnel. Nowadays the tunnel has been rebuilt (Figure $4 \mathrm{~b}$ ). It has got a parallel European and wide gauge railway. Such a technical solution in the tunnel is the only one in the world. 
a)

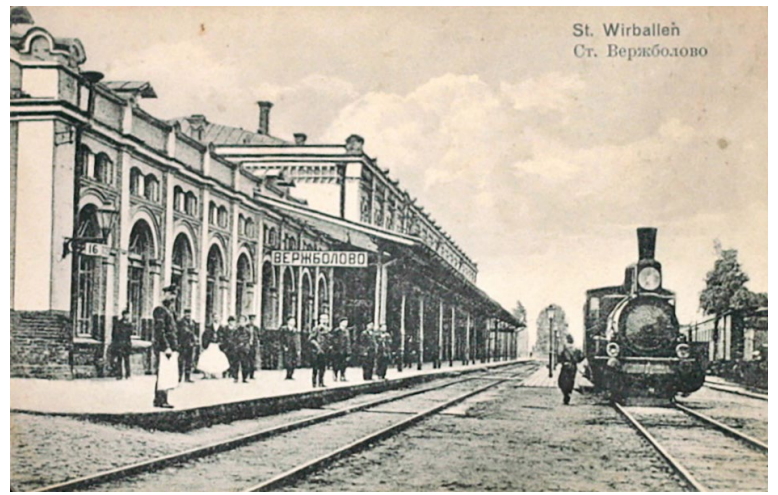

b)

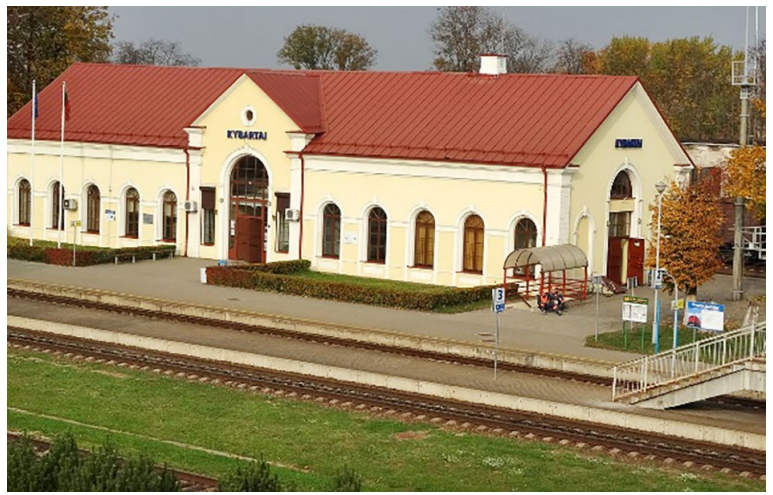

Figure 3. Railway station: a - Virbalis railway station at the juncture of the 19 and 20th centuries (Mickevičius 2007); b - Kybartai railway station today (Wikipedia 2021a)

a)

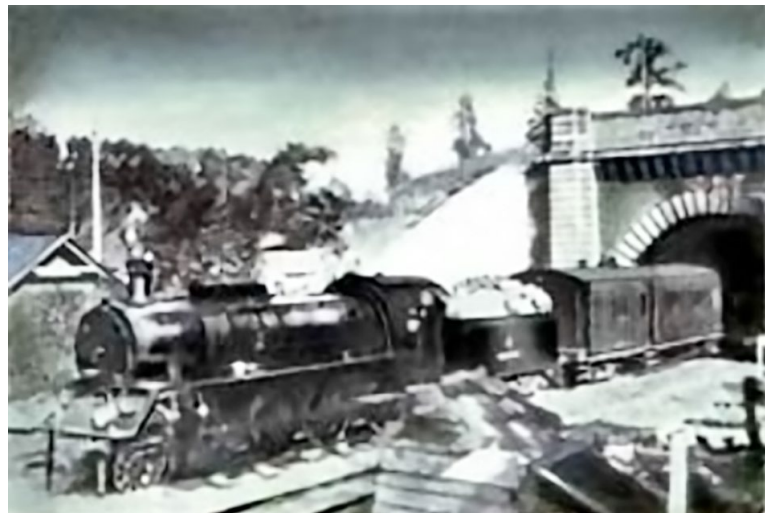

b)

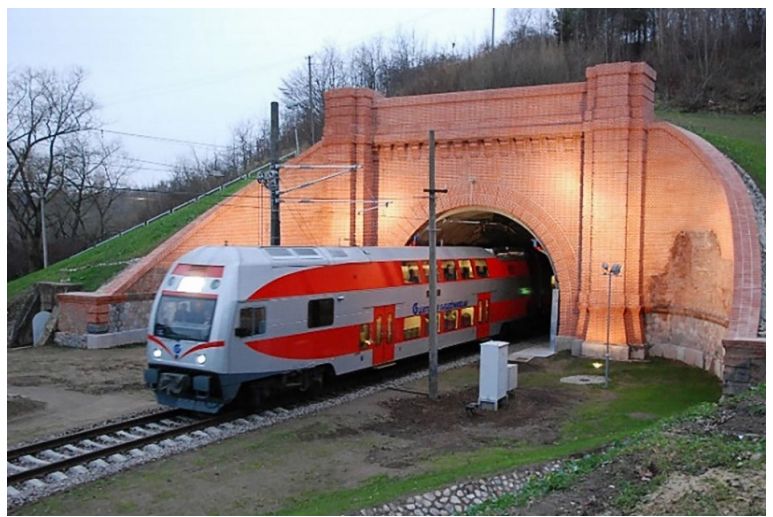

Figure 4. Kaunas tunnel (photos by Lithuanian Railway Museum): a - train near Kaunas tunnel, interwar period; b - rebuilt Kaunas railway tunnel

In 1861, a multi-storey brick passenger building of Vilnius railway station, as well as other railway buildings were built. The first-, second- and third-class passenger halls of Vilnius railway station had buffets owned by Vilnius merchant A. Livshic. At the beginning of 1866, the Governor-General agreed to open a bookshop in the railway station, which could trade only in Russian publications. The press in tsarist Russia was strictly supervised. This shop was constantly inspected by railway gendarmes. The importance of Vilnius station was constantly growing. In 1882, the Vilnius railway station of the Saint-Petersburg-Warsaw line was divided into passenger station and freight station (Žeimantas 2003).

The Saint-Petersburg-Warsaw railway was one of the first railways in Russia and it was built when there were no general normative requirements and standards for railways. When the process of the construction of new railways advanced, the need occurred for the exchange of freight wagons and organization of direct passenger train traffic. In addition, the issues of unification (standardization) of roads and rolling stock evolved. On 18 March 1860, Russian Ministry of Transport approved the dimensions of all wide rolling stock, track gauge, minimum gauges of adjacent tracks, buildings adjacent to the railway track, minimum distances from track curb, which were mandatory for all railways and which in principle have been valid in Lithuania to this day (Žeimantas 2003).

The train traffic was not heavy on the first railways. The trains travelled on schedule. As the number of trains increased, an alarm system became necessary. The first signals were introduced. The Saint-Petersburg-Warsaw railway played a great role in the establishment of railway signalling system in Russia (ID 2021). With the increase in numbers of railway companies and the differences in the style and results of their operation, in 1889 the Russian Ministry of Finance, at the request of the Tsar, invited S. Vitte (Minister of Finance from 1892 to 1903), who was a specialist in railway economic activities, to run the newly established Railway Department. On 1 March 1891, strict budgeting procedures entered into force. The government increasingly interfered in the activities of private companies (Žeimantas 2003).

In the first years of railway operation in Russia, the raising of passenger ticket fares was common, as revenues did not cover the costs. However, high ticket fares prevented people from using the railway. Russia, with its rapidly built railways, lagged far behind in the numbers of transporting passengers. In 1891, only $43.5 \mathrm{mln}$. passengers travelled by rail in Russia. In Germany the number of rail passengers reached $315 \mathrm{mln}$., in the United King- 
dom there were $817 \mathrm{mln}$. of rail passengers and in small Belgium there were $57 \mathrm{mln}$. of rail passengers. There were only 1600 rail passengers per 500 fathoms $(1.067 \mathrm{~km})$ in Russia per year. In Austria, the figure was 4800, in Prussia it was 13000 and in Saxony 15000. High ticket fares scared passengers away from the railways. The number of railways increased and the number of passengers per distance unit decreased. The Hungarian railways boldly reduced ticket fares. The price reduction led to the increase of passengers travelling by rail. The numbers of passengers almost doubled. In 1888, there were 70605 rail passengers, and after the price reduction in 1891 the numbers of rail passengers increased to 121828). The Russians understood that reasonable tariff reductions can increase rail revenues. Therefore, in 1891, the Ministry of Finance started to consider the reform of passenger tariffs. Private railway companies understood this reality earlier, and reduced passenger fares in some directions of Saint-Petersburg-Warsaw railway line. In 1875, the Chief Russian Railway Company cut fares for passengers travelling from Saint-Petersburg to Virbalis and Warsaw.

Daily traffic intensity of Saint-Petersburg-Warsaw railway in winter and summer of 1865 in both directions is presented in Table 3.
The construction of the railway showed that there was a great problem with the staff for servicing the railway performance. Russia was then an illiterate state. The situation in Lithuania was not much better either. There were only one or two secondary schools (gymnasiums) in each of the provinces, and those trained there could hold only the lowest positions in the administrative units. The network of military schools was managed by Tsarist authorities better. So, officers and non-commissioned officers could work in the railway maintenance and construction services, but they also had to be retrained. The military transport issue was addressed by Tsarist authorities in Saint-Petersburg, where in 1809, the Saint-Petersburg Institute of River and Land Transport Engineers was founded, which in 1810 was named Saint-Petersburg Institute of Transport Engineers. With the intensive construction of railways in Europe and America, the institute became interested in railways. In 1864, Saint-Petersburg Institute of Transport Engineers was reformed into Civil Institute of Transport Engineers, where railway disciplines became the primary ones. The students at this institute managed the state and private railways in Lithuania until the end of the tsarist rule (Žeimantas 2003).

Table 3. Traffic intensity of Saint-Petersburg-Warsaw railway in 1865 (trains/day) (Žeimantas 2003)

\begin{tabular}{|c|c|c|c|c|c|c|c|c|c|c|}
\hline \multirow{3}{*}{ Route } & \multicolumn{5}{|c|}{ Train traffic intensity in winter } & \multicolumn{5}{|c|}{ Train traffic intensity in summer } \\
\hline & \multicolumn{5}{|c|}{ Train category } & \multicolumn{5}{|c|}{ Train category } \\
\hline & Courier & Passenger & $\begin{array}{c}\text { Additional } \\
\text { passenger }\end{array}$ & Freight & $\begin{array}{c}\text { Additional } \\
\text { freight }\end{array}$ & Courier & Passenger & $\begin{array}{l}\text { Additional } \\
\text { passenger }\end{array}$ & Freight & $\begin{array}{c}\text { Additional } \\
\text { reight }\end{array}$ \\
\hline Saint-Petersburg-Warsaw & 2 & 2 & 2 & - & - & 2 & 2 & 2 & - & - \\
\hline Vilnius-Warsaw & - & 2 & - & - & - & - & 4 & - & - & - \\
\hline Daugavpils-Vilnius & - & - & - & 2 & 2 & - & - & - & 2 & 2 \\
\hline Vilnius-Virbalis & - & - & - & 2 & 2 & - & - & - & 2 & 2 \\
\hline Vilnius-Lapai & - & - & - & 2 & - & - & - & - & 2 & - \\
\hline
\end{tabular}

Table 4. The number of railway employees by nationality and gender in Lithuanian provinces (Žeimantas 2003)

\begin{tabular}{|c|c|c|c|c|c|c|c|}
\hline \multirow{2}{*}{ Nationality } & \multicolumn{2}{|c|}{ Kaunas province } & \multicolumn{2}{|c|}{ Suvalkai province } & \multicolumn{2}{|c|}{ Vilnius province } & \multirow{2}{*}{ Total } \\
\hline & male & female & male & female & male & female & \\
\hline Russians & 337 & 18 & 114 & - & 1321 & 108 & 1898 \\
\hline Ukrainians & 3 & - & 1 & - & 23 & 3 & 30 \\
\hline Of Belarussian origin & 14 & 8 & 1 & - & 637 & 67 & 727 \\
\hline Poles & 645 & 128 & 96 & 8 & 1330 & 165 & 2372 \\
\hline Other Slavs & - & - & - & - & 2 & - & 2 \\
\hline Lithuanians & 278 & 41 & 216 & 54 & 318 & 43 & 950 \\
\hline Samogitians & 377 & 40 & 1 & - & 4 & - & 422 \\
\hline Latvians & 48 & 13 & - & - & - & - & 61 \\
\hline Germans & 28 & 1 & 131 & 7 & 43 & 1 & 211 \\
\hline Jews & 39 & 2 & 11 & 5 & 63 & 1 & 121 \\
\hline Turks and Tatars & 1 & - & - & - & 2 & - & 3 \\
\hline Finns & - & - & - & - & 2 & - & 2 \\
\hline Total & 1770 & 251 & 571 & 74 & 3745 & 388 & 6799 \\
\hline
\end{tabular}


For the maintenance of rolling stock, workers were attracted from few metal and blacksmith companies. However, in times of serfdom, there were few free people working there. The first railway technical school opened in Jelce in 1869 and it trained the middle level railway workers. Later, this school became a model for other railway technical schools, including the one in Vilnius. The cheapest and the fastest way to prepare lower-level workers could be the training of local people, but the tsarist authorities did not trust people of other nationalities and especially people of other religions. The composition of railway employees by nationality and gender in Lithuanian provinces is presented in Table 4.

Lithuanians were divided into Aukshtaitians (in Lithuanian: aukštaičiai, they were called Lithuanians) and Samogitians (in Lithuanian: žemaičiai). A lot of Samogitians lived in Kaunas province. In other localities Samogitians were considered as Lithuanians. Table 4 illustrates that the railway administration was against local nationalities in Lithuanian provinces. The situation was especially evident on the Saint-Petersburg-Warsaw railway line, since the railway administration witnessed the 1863 Uprising in Lithuania and M. Murav'jov - the Hanger's drastic distrust in Catholics. There were demands to take Orthodox instead of Catholics. The managers of the railways, which were built many years after the Uprising were more tolerant to local people, so there were more Lithuanians (Aukshtaitians and Samogitians) working there (Žeimantas 2003).

\section{A look at the future of Lithuania with the European railway Rail Baltica}

Railway is a vital means of transport, which plays a key role in working out the issues related to reduction of traffic flows, easing congestions, security of fuel supply and reduction of dependence on fossil fuels. To ensure greater numbers of passengers travelling by trains and more freight transported by railway, it is essential to improve services and make them more attractive to customers (Lichtberger 2015).

The history of the railway origin has decided the building of the so-called Russian 1520 mm track gauge (Wikipedia 2021b) in Lithuania. Over time, with the changing geopolitical situation, the rapid development of technology, the changing needs of passengers and the increasing mobility of goods, it has become clear that the old railways have become morally obsolete. The first international convention on rail freight, which was signed in 1890, aimed to open Europe up to cross-border rail transport. Nevertheless, different national standards were used in rail transport in European countries including different gauges, signalling systems and rules. With the view to create a single European railway area, European Rail Traffic Management System (ERTMS, https://www.ertms.net) was launched in the late 1990s, with the aim of replacing all existing different signalling systems in Europe with a single system. The system would ensure interoperability between national rail networks and cross-border rail transport. Trains would pass EU countries without any disruptions, the competitiveness of railway transport would be promoted, traffic safety would be ensured (Rail-Baltica.lt 2021b).

The current total length of Lithuanian railway network lines is $1910.7 \mathrm{~km}$. Rail Baltica is a rail transport infrastructure project that aims to integrate the Baltic States into the European railway network. The project total value is about 5.8 billion $€$, and it is the largest investment aimed at the enhancement of mobility in the region, development of business, tourism, and trade. The project involves 5 EU countries (Figure 1b): Poland, Lithuania, Latvia, Estonia, and Finland. The latter is involved indirectly. The line will connect Helsinki, Tallinn, Pärnu, Riga, Panevéžys, Kaunas, Vilnius, and Warsaw. The technical parameters of Rail Baltica are presented in Table $5.870 \mathrm{~km}$ of high-speed electrified railway double-track will be built in Lithuania, Latvia, and Estonia. The ongoing project will have an electrified railway line operated by ERTMS. Implementation of Rail Baltica in Lithuania is divided into 3 sections (RailBaltica.lt 2021b): Polish/Lithuanian-state-border-Kaunas, Kaunas-Vilnius and Kaunas-Lithuanian/Latvian-stateborder. In 2015, a $1435 \mathrm{~mm}$ wide European gauge was built and put into operation on the TEN-T railway transport network (Figure 2b) in the first section of the railway from the Polish/Lithuanian state border to Jiesia (Kaunas). This section is planned to be modernized by 2026 and will bring the design speed of passenger trains to $249 \mathrm{~km} / \mathrm{h}$. Kaunas intermodal terminal is connected to the EU railway system. According to preliminary calculations, from 2030 to 2040, Rail Baltica railway line via Kaunas will annualy be used by more than $4.5 \mathrm{mln}$. passengers.

Rail Baltica will act as an extensive catalyst for the continued economic development of the Baltic States and during the construction phase it will boost hundreds of new jobs and will contribute to the region's Gross Domestic Product (GDP). It will also reduce the distance between the Baltic countries and bring the rest of Europe closer. A modern high-speed rail link will provide a convenient,

Table 5. Technical parameters of Rail Baltica (RailBaltica.org 2021)

\begin{tabular}{|l|l|}
\hline \multicolumn{1}{|c|}{ Parameter } & \multicolumn{1}{c|}{ Dimension } \\
\hline Total line length & $\begin{array}{l}870 \mathrm{~km} \text {, of which: } \\
\text { "' } 213 \mathrm{~km} \text { in Estonia; } \\
\text { "» } 265 \mathrm{~km} \text { in Latvia; } \\
\text { "' } 392 \mathrm{~km} \text { in Lithuania }\end{array}$ \\
\hline Design speed & $\begin{array}{l}\text { "' passenger trains }-249 \mathrm{~km} / \mathrm{h} \\
\text { "» freight trains }-120 \mathrm{~km} / \mathrm{h}\end{array}$ \\
\hline Standard gauge & $1435 \mathrm{~mm}$ \\
\hline Electrified double-track line & $2 \times 25 \mathrm{kV} \mathrm{AC}$ \\
\hline Axle load & $25 \mathrm{t}$ \\
\hline Traffic management & ERTMS L2 \\
\hline $\begin{array}{l}\text { Maximum length of freight } \\
\text { trains }\end{array}$ & $1050 \mathrm{~m}$ \\
\hline
\end{tabular}


safe, and environmentally friendly alternative for passenger movement. Passengers in the Baltic States will enjoy travel opportunities in terms of quality, speed, convenience, and passenger experience as have long been available in Western Europe. The bar chart (Figure 5) illustrates that flights between the capitals of the Baltic States are only a little shorter than high-speed train trips when travelling by Rail Baltica. The advantages of train travel as an alternative to air travel are described in the publication by Sivilevičius and Maskeliūnaite (2018). The outcomes of the author's research on the advantages of rail transport compared to travel by bus will be published in another article.

Cargo owners and freight forwarding agents will be able to simplify their supply chain processes through direct and unhindered, high-capacity access to the European rail system. Rail Baltica project will promote the transition of railway specialists from the more traditional segments of the Baltic railway industry to the new European gauge railway system. After a while, there will be qualified specialists with experience in both railway systems. With the start of the operational phase of the project, new permanent jobs will be created in the areas of infrastructure management and maintenance, station, and terminal management, as well as in the area of all types passenger and freight management. At the macroeconomic level, Rail Baltica will significantly improve the accessibility of the Baltic labour market, as well as reduce the environmental impact of the movement of people in the Baltic States. The implementation of the shift from road to rail (passenger and freight) will significantly reduce the monetary impact of climate change due to economies of scale, road maintenance costs and noise pollution (Rail-Baltica. lt 2021a).

Rail Baltica will benefit both residents of the region and businesses. The European railway from Palemonas (Kaunas) will be built towards Latvia. A special plan has been prepared for the development of this section. Environmental impact assessment and land acquisition for public needs have also been carried out. Currently, the plan for the communication engineering infrastructure of the Kaunas-Vilnius section is under development (LR SM 2021b).

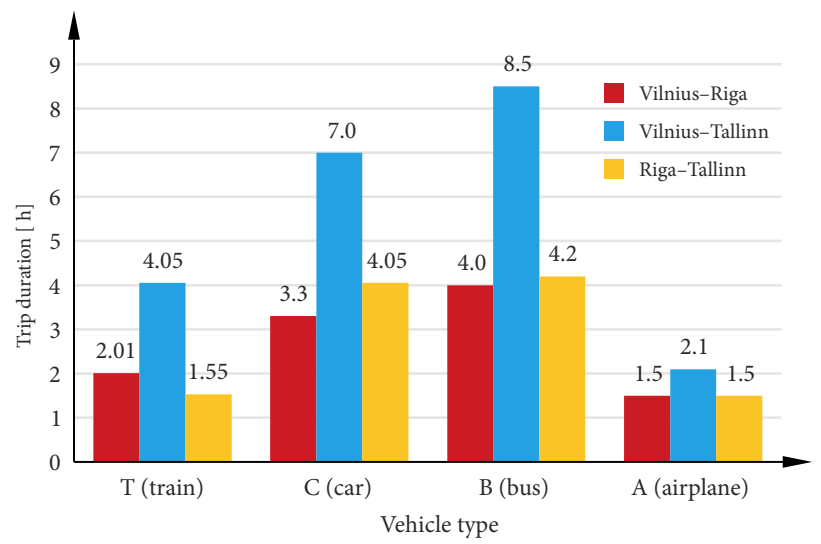

Figure 5. Travel time between the capitals of the Baltic States when travelling by Rail Baltica (T) and other modes of transport
An architectural call for proposals for Vilnius railway station and the surrounding district has been announced (Rail-Baltica.lt 2021c). The proposals will put forward the visions, which will change this transport hub to a modern attraction centre. For future travellers on Rail Baltica railway lines, Vilnius railway station will be the most cutting-edge city gates in the Baltic States. There is no doubt that there will be the increase in rail passengers in the future. For this purpose, Joint-Stock Company "Lietuvos geležinkeliai” (LTG - Lithuanian Railways) is developing a special application to plan convenient, fast and environmentally friendly travel routes. It will integrate different modes of transport. It is planned that the launch of Rail Baltica trains between Warsaw and Tallinn will significantly increase the number of foreign tourists, for whom train transport will become a convenient and fast way to visit the Baltic countries. It is also discussed that Rail Baltica railway connection will have a direct access to Vilnius and Kaunas airports (LR SM 2021c). The project is expected to be completed by the end of 2026 .

The pandemic has restricted train travel. The passenger transport company "LTG Link" estimates that $3.3 \mathrm{mln}$. passengers travelled by local and international trains in 2020 , which is $40 \%$ of passengers less than in 2019. Last year was also full of challenges for the company "LTG Cargo". This was due to the difficult situation in industrial enterprises caused by the pandemic and the insecure geopolitical situation in the region. In 2020, the carrier transported $3 \%$ less cargo $-53.4 \mathrm{mln}$. tons (LR SM 2021a). Due to EU sanctions against Belarus following the event when on 23 May 2021, A. Lukashenko regime forcibly landed in Minsk the plane flying from Athens to Vilnius, LTG has estimated that the company would lose up to $20 \mathrm{mln}$. $€$ income. The package of sanctions includes cargo that crosses the Belarusian border to Lithuania in various directions. Losses due to fertilizers would amount to $14 \mathrm{mln}$. $€$, and the loss of transportation of oil products would be $4 . . .5 \mathrm{mln}$. €/year (Naprys 2021).

The EC (2021) has declared 2021 the European Year of Rail and will encourage Europeans to use railways throughout the year and contribute to the European Green Deal goal of moving to a climate-friendly economy by 2050 (EC 2019). The aims of the EU overall environmental strategy is to redistribute freight transport. That will held for rail and maritime transport redistribute freight transport account for at least $50 \%$ for all freight. It is likely that Rail Baltica freight traffic will increase significantly in the future. Freight transport by rail is perspective due to the fact of congested container market and tightening restrictions on the sulfur content for maritime fuels. According to the research of the European Commission, the positive impact of investments in transport infrastructure projects on the economy and the labor market will continue until 2030. It is planned that the mentioned investments will help to create $10 \mathrm{mln}$. jobs positions in the European Union and GDP growth in this area alone will be 1.8\% (RailBaltica.lt 2021d). 


\section{Conclusions}

Rail transport is one of the oldest modes of transport, dating back to ancient Greece and Egypt. The history of Lithuanian railways starts from Tsarist Russia when the Saint-Petersburg-Warsaw railway line was built. During the construction of this railway, railway stations, bridges and tunnels were built in the territory of present-day Lithuania. Rail transport faced challenges: there were no common regulatory requirements, standards, signalling systems for the operation of railways, and passenger revenues did not cover expenses. The construction of railways was problematic as the construction and maintenance of the railway required qualified specialists and there were no schools to train them. There was a particular shortage of ordinary workers, as training of low-level workers from the local people was prevented by the distrust of the tsarist authorities towards other nationalities.

It has been a long time since the first railway was built. With the advent of the first locomotive-drawn trains, nobody considered the idea of transporting freight and passengers on a large scale, also of environment protection. Times, regimes, and orders have been changing. Railways and rolling stock have been improving. This can be linked to the development of society itself: the change of needs, values, and generations. The second half of the 20th century marked the start of the global ecological crisis. Less polluting and environmentally friendly energy sources have been introduced. One of the paramount tasks of Lithuanian railways today is integration into the common European transport network - Rail Baltica.

Lithuania does not have a high-speed railway infrastructure therefore road and air transport is the dominant mode of travel. With the view to the reduction of travel time between the capitals of the Baltic States, only air transport is faster compared to Rail Baltica traveling by rail. The opportunities of the Baltic States to reach the single European market have not reached their full potential yet and are still untapped. Rail Baltica will fill this gap. The project will create the missing link with Western Europe and in this way will restore the historical justice. The Baltic States will be reintegrated into the European railway system.

\section{References}

Bogdevičius, M.; Žygienė, R.; Dailydka, S.; Bartulis, V.; Skrickij, V.; Pukalskas. S. 2015. The dynamic behaviour of a wheel flat of a railway vehicle and rail irregularities, Transport 30(2): 217-232.

https://doi.org/10.3846/16484142.2015.1051108

ERA. 2020. Report on Railway Safety and Interoperability in the $E U$. European Union Agency for Railways (ERA). 116 p. https://doi.org/10.2821/30980

EC. 2019. Communication from the Commission to the European Parliament, the European Council, the Council, the European Economic and Social Committee and the Committee of the Regions - The European Green Deal. COM/2019/640 final. 11/12/2019, Brussels, European Commission (EC). Available from Internet: https://eur-lex.europa.eu/legal-content/EN/ ALL/?uri=COM:2019:640:FIN

EC. 2021. European Year of Rail. European Commission (EC). Available from Internet:

https://europa.eu/year-of-rail/index_en

Gailienè, I. 2012. Investigation into the calculation of superelevation defects on conventional rail lines, Transport 27(3): 229-236. https://doi.org/10.3846/16484142.2012.719198

Horvatova, E. V. 2011. Nikolaj II. Lichnaja zhizn' imperatora. AST-Press. 696 s. (in Russian).

Hrustalev, V. M. 2008. Dnevniki Nikolaja II i imperatricy Aleksandry Fedorovny. 1917-1918. Vagrius. 1280 s. (in Russian).

Husainov, F. 2021. Sozdanie pervoj zheleznoj dorogi v Rossii: kak vse bylo na samom dele. Available from Internet: https://spec.rzd-partner.ru/page1907927.html (in Russian).

ID. 2021. Peterburgo-Varshavskaja zheleznaja doroga. Inovacionnyj dajdzhest (ID): vsjo samoe interesnoe o zheleznoj doroge. Available from Internet: http://www.rzd-expo.ru/history/ petersburg-warshaw_railway/(in Russian).

Ivaškevičius, M. 2013a. Civilizacija Veržbolovo - I dalis. Available from Internet: https://kybartai.lt/lt_lt/civilizacija-verzbolovoi-dalis/ (in Lithuanian).

Ivaškevičius, M. 2013b. Civilizacija Veržbolovo - II dalis. Available from Internet: https://kybartai.lt/lt_lt/civilizacija-verzbolovo-ii-dalis/ (in Lithuanian).

Kunčius, H. 2018. Lietuviškos apybraižos: istoriju romanas. Vilnius: Lietuvos rašytojų sąjungos leidykla. 253 p. (in Lithuanian).

Li, X.; Fang, J.; Zhang, Q.; Zhao, S.; Guan, X. 2020. Study on key technology of railway freight car body fatigue test, Journal of Failure Analysis and Prevention 20(1): 261-269.

https://doi.org/10.1007/s11668-020-00828-7

Lichtberger, B. 2015. $1435 \mathrm{~mm}$ pločio véžés geležinkelio kelias: žinynas. Vilnius: Zidex. 306 p. (in Lithuanian).

LR SM. 2021a. LTG skaičiuoja sudetingu 2020 m. rezultatus: geriau nei planuota, visi strateginiai projektai važiuoja pirmyn. Lietuvos Respublikos susisiekimo ministerija (LR SM). Available from Internet: https://sumin.lrv.lt/lt/naujienos/ltg-skaiciuoja-sudetingu-2020-m-rezultatus-geriau-nei-planuota-visistrateginiai-projektai-vaziuoja-pirmyn (in Lithuanian).

LR SM. 2021b. „Rail Baltica“atveria nauju galimybiu Kauno regionui. Lietuvos Respublikos susisiekimo ministerija (LR SM). Available from Internet: https://sumin.lrv.lt/lt/naujienos/rail-baltica-atveria-nauju-galimybiu-kauno-regionui (in Lithuanian).

LR SM. 2021c. Susisiekimo ministras: „Rail Balticos“ europinio geležinkelio jungtis turi tiesiogiai pasiekti Vilniaus ir Kauno oro uostus. Lietuvos Respublikos susisiekimo ministerija (LR $\mathrm{SM}$ ). Available from Internet: https://sumin.lrv.lt/lt/naujienos/susisiekimo-ministras-rail-balticos-europinio-gelezinkelio-jungtis-turi-tiesiogiai-pasiekti-vilniaus-ir-kauno-orouostus (in Lithuanian).

LR SM. 2021e. The Aim of the Baltic States is Rapid and Coordinated Implementation of the "Rail Baltica" Project. Ministry of Transport and Communications (LR SM). Available from Internet: https://sumin.lrv.lt/en/news/the-aim-of-the-balticstates-is-rapid-and-coordinated-implementation-of-the-railbaltica-project

Maskeliūnaite, L.; Sivilevičius, H. 2020. The model for evaluating criteria describing the internal safety of a railway trip by international train, in: K. Gopalakrishnan, O. Prentkovskis, I. Jackiva, R. Junevičius (Eds.). TRANSBALTICA XI: Transportation Science and Technology, 2-3 May 2019, Vilnius, Lithuania, 610-621. https://doi.org/10.1007/978-3-030-38666-5_64

Maskeliūnaite, L.; Sivilevičius, H. 2014. The model for evaluating the criteria describing the quality of the trip by international train, 
Technological and Economic Development of Economy 20(3): 484-506. https://doi.org/10.3846/20294913.2014.949333

Mickevičius, V. 2007. Kybartai senuosiuose atvirukuose. Tado Skaurono internetinis puslapis "Kybartų miesto istorija". Available from Internet:

https://kybartai.weebly.com/kybartai-senuosiuose-atvirukuose.html

Mintzia, D.; Kehagia, F.; Tsakalidis, A.; Zervas. E. 2018. A methodological framework for the comparative analysis of the environmental performance of roadway and railway transport, Promet - Traffic \& Transportation 30(6): 721-731. https://doi.org/10.7307/ptt.v30i6.2804

Naprys, E. 2021. ES sankcijos Baltarusijai nuo „Lietuvos geležinkeliü" nubrauks iki $20 \mathrm{mln}$. euru pajamų. (in Lithuanian). Available from Internet: https://www.delfi.lt/verslas/ transportas/es-sankcijos-baltarusijai-nuo-lietuvos-gelezinkeliu-nubrauks-iki-20-mln-euru-pajamu.d?id=87556465

Navikas, D.; Bulevičius, M.; Sivilevičius, H. 2016. Determination and evaluation of railway aggregate sub-ballast gradation and other properties variation, Journal of Civil Engineering and Management 22(5): 699-710.

https://doi.org/10.3846/13923730.2016.1177586

Navikas, D.; Sivilevičius, H.; Bulevičius, M. 2018. Investigation and evaluation of railway ballast properties variation during technological processes, Construction and Building Materials 185: 325-337.

https://doi.org/10.1016/j.conbuildmat.2018.07.090

Prizova, E. 2014. Chetyre ljubopytnyh fakta o Nikolaevskoj zheleznoj doroge, Rossijskaja gazeta 12 fevralja 2014 goda. Available from Internet:

https://rg.ru/2014/02/12/poezda-site.html (in Russian).

Rail-Baltica.lt. 2021a. 10 projekto „Rail Baltica“ igyvendinimo privalumu. „Rail Baltica“ koordinavimo departamentas, AB „LTG Infra“, Vilnius, Lietuva. Available from Internet: https://www.rail-baltica.lt/nauda/ (in Lithuanian).

Rail-Baltica.lt. 2021b. Europiečiu susisiekimq užtikrins tvariausias transportas - traukiniai. „Rail Baltica“ koordinavimo departamentas, AB „LTG Infra“, Vilnius, Lietuva. Available from Internet: https://www.rail-baltica.lt/naujienos/europieciususisiekima-uztikrins-tvariausias-transportas-traukiniai/ (in Lithuanian).

Rail-Baltica.lt. 2021c. Sostinès geležinkelio stotis taps viena moderniausių Baltijos šalyse. "Rail Baltica“ koordinavimo departamentas, AB „LTG Infra“, Vilnius, Lietuva. (in Lithuanian). Available from Internet: https://www.rail-baltica. lt/naujienos/sostines-gelezinkelio-stotis-taps-viena-moderniausiu-baltijos-salyse/

Rail-Baltica.lt. 2021d. Su „Rail Baltica“ po Europa keliausime greičiau, saugiau ir patogiau. "Rail Baltica“ koordinavimo departamentas, AB „LTG Infra“, Vilnius, Lietuva. Available from Internet: https://www.rail-baltica.lt/naujienos/su-railbaltica-po-europa-keliausime-greiciau-saugiau-ir-patogiau/ (in Lithuanian).

RailBaltica.org. 2021. Technical Parameters. RB Rail AS, Riga, Latvia. Available from Internet: https://www.railbaltica.org/ about-rail-baltica/tehnical-parametrs/

Sivilevičius, H.; Maskeliūnaitè, L. 2018. Multiple criteria evaluation and the inverse hierarchy model for justifying the choice of rail transport mode, Promet - Traffic \& Transportation 30(1): 57-69. https://doi.org/10.7307/ptt.v30i1.2417

Sivilevičius, H.; Maskeliūnaite, L. 2019. The model assessing the impact of price and provided services on the quality of the trip by train: MCDM approach, E\&M Economics and Management 22(2): 51-67.

https://doi.org/10.15240/tul/001/2019-2-004
Sivilevičius, H.; Maskeliūnaite, L.; Petkevičienė, B.; Petkevičius, K. 2012. The model of evaluating the criteria, describing the quality of organization and technology of travel by international train, Transport 27(3): 307-319.

https://doi.org/10.3846/16484142.2012.724448

Vaičiūnas, G.; Steišūnas, S.; Bureika, G. 2021. Specification of estimation of a passenger car ride smoothness under various exploitation conditions, Eksploatacja i Niezawodność - Maintenance and Reliability 23(4): 719-725.

https://doi.org/10.17531/ein.2021.4.14

Vanagas, J. 2017. Konkè: the first public transport in Vilnius, Transport 32(1): 94-100. https://doi.org/10.3846/16484142.2016.1167124

Veidas.lt. 2010. Išnykusiu cariniu sienu pédsakai. Available from Internet: http://www.veidas.lt/isnykusiu-cariniu-sienu-pedsakai (in Lithuanian).

Venclova, T. 2019. Lietuvos istorija visiems. II tomas. Vilnius: R. Paknio leidykla. 384 p. (in Lithuanian).

Zygar, M. 2020. Imperija turi mirti: Rusijos revoliuciju istorija veikeju akimis, 1900-1917. Vilnius: Kitos knygos. 568 p. (in Lithuanian).

Žeimantas, L. V. 2003. Sankt Peterburgo - Varšuvos geležinkelis 1858-1915. Vilnius: Gelspa. 249 p. (in Lithuanian).

Wikipedia. 2021a. Kybartu geležinkelio stotis. Available from Internet: https://lt.wikipedia.org/wiki/Kybart\%C5\%B3_ gele\%C5\%BEinkelio_stotis (in Lithuanian).

Wikipedia. 2021b. Shirina kolei. Available from Internet: https://ru.wikipedia.org/wiki/Ширина_колеи (in Russian). 